coronary and carotid disease. However, carotid artery stenosis should not be overlooked as a prima facie correctable source of postoperative stroke.

M I ALDOORI

G L BENVENISTE R N BAIRD

Bristol Royal Infirmary,

Bristol BS2 8HW

1 Kartchner MM, McRae LP. Guidelines for non-invasive evaluation of asymptomatic carotid bruits. Clin Neurosurg 1981;28 tion of
$418-28$.

2 Baird RN, Aldoori MI, Cole SEA, Jeans WD. Preoperative assessments-cerebral revascularisation. In: Greenhalgh assessments-cerebral revascularisation. In: Greenhalg vascular surgery. London: Grune and Stratton, 1985:105.

\section{What is "serum albumin"?}

SIR,- - Two recent articles have drawn conclusions from serum albumin data which only add to the existing confusion surrounding the clinical importance of albumin measurements.

The first article, by Dr P Dandona and colleagues (2 November, p 1253), describes an association between hypoalbuminaemia and hyponatraemia and defines hypoalbuminaemia as a serum concentration of less than $32 \mathrm{~g} / \mathrm{l}$; the second by Professor Miles Irving (16 November, p 1404), suggests that a serum albumin concentration of les than $30 \mathrm{~g} / \mathrm{l}$ is one criterion of malnutrition in inpatients. In the second paper (and presumably in the first) statements are based on the measuremen of albumin by its dye binding properties with bromocresol green. ${ }^{1}$ Although widely used, this method is not specific for albumin in serum and can overestimate concentrations by as much as $100 \%$.

The figure compares the distribution of plasma albumin values in 1000 inpatients measured by the non-specific bromocresol purple method and by a specific method using bromocresol purple. The accuracy of the bromocresol green method com pares favourably with that of immunochemical methods. ${ }^{3}$ An apparent albumin concentration of less than $30 \mathrm{~g} / \mathrm{l}$ (or $32 \mathrm{~g} / \mathrm{l}$ ) is uncommon with the bromocresol green method, but about $50 \%$ of inpatients show concentrations below $30 \mathrm{~g} / \mathrm{l}$ if the bromocresol purple method is used.

The authors of the two recent articles are not in our opinion describing changes in "serum albumin" but alterations in "bromocresol green binding proteins," which will reflect changes both in albumin and in some globulins. A major component of the non-specificity of bromocresol green arises from reaction of the dye with acute phase proteins, ${ }^{4}$ which in many clinical conditions will increase in concentration as albumin decreases.

As one of us has pointed out, the clinical indications for the measurement of serum albumin are poorly defined. ${ }^{3}$ Wider adoption of specific methods is essential if the relevance of albumin determination to routine clinical practice is to

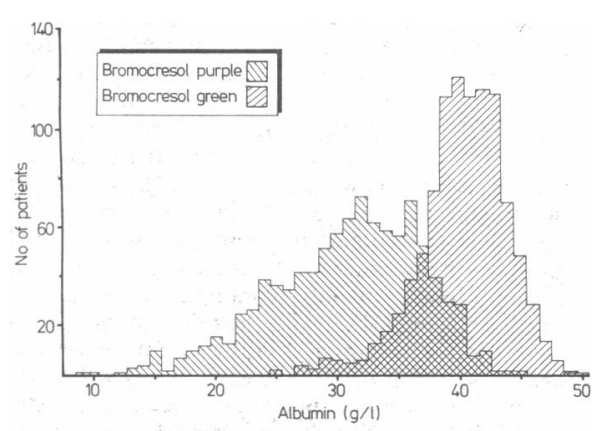

Distribution of plasma albumin in 1000 patients as measured by bromocresol green and bromocresol purple. be clarified. Perhaps conclusions concerning the hypoalbuminaemic hyponatraemia debate would be that much clearer if true albumin had been measured. Malnutrition is undoubtedly one cause of hypoalbuminaemia, but data from non-specific albumin methods are unlikely to provide an accurate basis for diagnosis and management.

P G HILL

Chemical Pathology Department,

J S HARROP

Derbyshire Royal Infirmary,

Derby DE1 2QY

1 Hill GL, Pickford I, Young GA, et al. Malnutrition in surgical patients: an unrecognised problem. Lancet 1977; i:687-92. Northam BE. Whither automation? Ann Clin Biochem 1980;18 $189-99$.

3 Hill PG. The measurement of albumin in serum and plasma. Ann Clin Biochem 1985;22:565-78.

4 Walsh RL. A comparison of dye-binding methods for albumin determination; the effects of abnormal sera, reaction times, acute phase reactants and albumin standards. Clin Biochem 1983;16:178-81.

\section{Should nurses practise prevention?}

SIR,-Dr W Reith (16 November, p 1394) raises interesting and important questions about the role of nurses in general practice. Let it not be thought, however, that such questions are new or have not been answered in other medical fields.

Occupational medical services have long established major roles for nurses trained in this specialty. They include a role in primary diagnosis and treatment for those seeking help with medical problems presenting at work; appropriate medical screening procedures for prospective employees, drivers, and others needing periodic fitness assessment for certain tasks; assessment of the working environment; inoculations and preventive care programmes for those going abroad on company service; the assessment of restricted workers and advice about suitable employment for them; and health education and health screening programmes.

Many nurses work on their own in small firms, sometimes in isolated locations, and need to be especially careful not to undertake duties which are more prudently done by a doctor. Others, with occupational health training, are in the delicate position of working with a doctor who may spend little of his time in occupational medicine and have no specialist training. In this situation, as well as in occupational health services with fully trained doctors and nurses, the doctors recognise that the nurses' role can be larger than that traditionally found in hospital or general practice and there are many things that either can do but the nurse does better.

Occupational health staff are learning all the time from National Health Service colleagues. We hope that they also will recognise the many lessons which can be learnt from us.

E BRILL

Brentwood

Essex CM13 3BW

I R SWANSON

\section{Not a divided elephant under Labour}

SIR,-Mr Philip Johnston's Letter from Westminster (14 December, $p$ 1735) is in error in several important respects and needs correcting.

Firstly, the Labour Party has no intention or plans to split the Department of Health and Social Security. Any suggestion of "a divided 'elephant' under Labour" is without any foundation. The article also casts doubt about my responsibility for health as well as social security. I really cannot see how any such idea can arise when I alone speak for health in the shadow cabinet, when I am the parliamentary spokesman for the health service on the Labour Party's national executive committee, and incidentally also an MP sponsored by the Confederation of Health Service Employees, and when I have spoken on endless platforms on the health service up and down Britain and continue to do so alongside my responsibility for social security, including the Fowler reforms.

The article says "It is Mr Dobson who now directs the policy initiatives of the party." This is simply not true. The Labour Party's policy making body on health-the national executive committee on health and personal social services-is chaired by me.

The charters on health that we are planning-on primary care, preventive health measures, inequalities in health, community care, and women's health issues-will be presented by me together with Frank Dobson. Much of the preparatory work for these charters was completed by seven working parties set up by me on key health service issues - primary care, health promotion, and preventive measures, NHS structure and organisation, women and health, and private medicine and privatisation. Almost all these have now presented their reports to me.

Finally, I would add that early in the new year I am expecting to launch campaigns based on NHS surveys I have been conducting concerning accident and emergency departments, family planning provision, membership of health authorities, and a national one on the state of the health service in 1986.

Michael Meacher

House of Commons

London SW1A 0AA

\section{The radiologists group and group committee}

SIR,-Last spring a ballot of members of this group was held to ascertain the views of radiologists on changing to a radiology subcommittee of the Central Committee for Hospital Medical Staff, with the following result: for 14 , against 120 . Nevertheless, the CCHMS has continued with plans to institute such a subcommittee despite protests from the group committee.

The group committee is due to meet on 23 January to decide whether to accept such a subcommittee and to ask for its own dissolution and that of the group at the end of the present session. A few concessions have been obtained and there will be almost as many members on the new committee as on the present - that is, 10 elected or coopted, two nominations from the Royal College of Radiologists, one from nuclear medicine, and one from the Hospital Junior Staff Committee. The Royal College of Radiologists has agreed to present a paper to its council after each meeting, and the CCHMS will also receive the minutes which it has repeatedly been offered in accordance with the rules governing group committees.

The disadvantage is in the loss of independence and of the group. The pathologists changed a few years ago but it is interesting that the last chairman of the pathologists group and the first chairman of the pathologists subcommittee wrote recently in Hospital Doctor: "It is now obvious that a chasm is opening between clinical and service departments, the former apparently being supported by both the HCSA [Hospital Consultants and Specialists Association] and the BMA. It may well be time for consultants in the service specialties to seek alternative forms of representation with direct access to the DHSS if equality in the ability to undertake private practice is to exist in the future."

The group committee is in a great dilemma, whether to accept its replacement by a subcommittee or to complain formally to the council of 